\author{
Maria TYCHANICZ ${ }^{1}$ \\ Robert SMUSZ ${ }^{2}$
}

\title{
PROPERTIES, APPLICATIONS AND THERMAL INVESTIGATION OF AEROGELS
}

\begin{abstract}
Among the variety of products for thermal insulation in industry the aerogel blankets have received significant attention because of their unique properties and wide range of applications. This paper presents the basic properties, fields of application and results of experimental study of Pyrogel XT, which is a type of high temperature aerogel blanket. It is formed of silica aerogel and reinforced with glass fiber batting. In comparison with traditional insulating materials Pyrogel XT is much more efficient thermal insulation with wide temperature range of application $\left(-40 \div 650^{\circ} \mathrm{C}\right)$. It also has the lowest thermal conductivity of any known solid material. Experimental investigation of thermophysical properties of Pyrogel XT was carried out by using traditional and modern research methods. The traditional method utilized a simplified single-plate Poensgen apparatus. The modern approach was performed on a Unitherm ${ }^{\mathrm{TM}}$ model 2022 thermal conductivity instrument which uses a guarded heat flow meter method according to ASTM E1530 standard. Results obtained from both devices were compared and analyzed.
\end{abstract}

Keywords: aerogel blanket, thermal conductivity, Poensgen apparatus, heat flux

\section{Introduction}

Aerogel materials have been in existence for more than 80 years. Aerogels are a diverse class of porous, solid materials that exhibit an uncanny array of extreme materials properties [1]. Most notably aerogels are known for their extreme low densities (from 1 to $500 \mathrm{~kg} / \mathrm{m}^{3}$ ) $[2,3]$ that result from high porosity and low coefficient of thermal conductivity (up to $0.013 \mathrm{~W} / \mathrm{mK}$ ) [1, 3-5]. The most popular are silica aerogels, which are an amorphous solid materials derived from silica based gel. The silica solids, which are a poor conductors consist of very small, three-dimensional intertwined clusters that make up about $3 \%$ of volume. The remaining $97 \%$ occupy the air of extremely small nanopores. This provides little space for air to move [2]. Thus, the combination of limited solid conduction and inhabited convection and gas-phase conduction leads to the re-

\footnotetext{
1 Autor do korespondencji/corresponding author: Maria Tychanicz, Politechnika Rzeszowska, 35-959 Rzeszów al. Powstańców Warszawy 12, tel. (17) 743-2299, e-mail: mtychanicz@prz. edu.pl

${ }^{2}$ Robert Smusz, Politechnika Rzeszowska, e-mail: robsmusz@prz.edu.pl
} 
markable thermal performance of aerogel materials. Proportions of silica and air are different. This ratio is usually 5:95, but there are some systems in which the ratio of silica to air is $0.13: 99.87$. The average size of the silica particles in aerogel reaches $2-5 \mathrm{~nm}$ and the average pore size is $20 \mathrm{~nm}$ [6].

\section{Synthesis of aerogels}

The advanced, complicated and troublesome manufacturing process of aerogels provides extraordinary physical, thermal, acoustic and optical properties of the final product. Almost all aerogels are derived from gels made through sol-gel chemistry [1]. The sol-gel process refers to a process in which solid nanoparticles dispersed in a liquid (a sol) conglomerate together to form a continuous, three-dimensional sponge- like solid network extending throughout the liquid (a gel) [1]. The synthesis of (silica) aerogels consists of three general steps: gel preparation by sol-gel process, ageing of the gel and drying of the gel under special conditions. Figure 1 presents the simplified diagram of an aerogel's process of production during supercritical drying process. Aerogels are created when the pore liquid is replaced by air without decisively altering the network structure or the volume of the gel body [7].

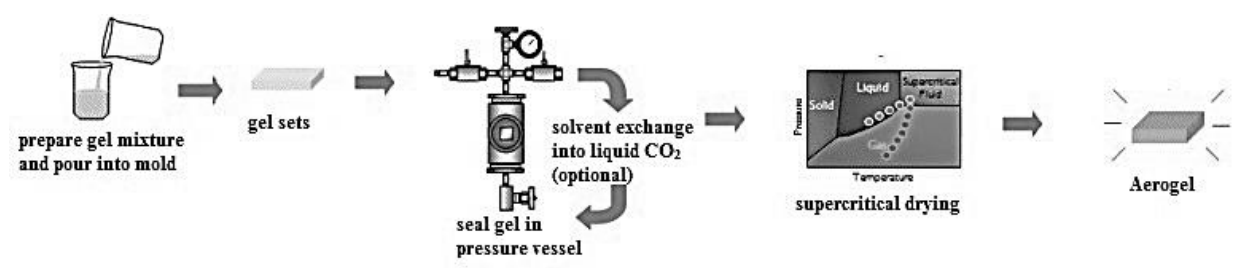

Fig. 1. An aerogel's process of production scheme during supercritical drying. Source: [7]

Pores distribution is usually irregular due to the different parameters of the chemical processes during synthesis which damage previously ordered internal structure. The most crucial stage affecting the internal porous structure is the drying process because of the possibility of the gel's shrinkage. The porous nature of aerogels is of great importance for its highly insulating properties. Conformation of pores, size, shape, density and porosity have a primary influence on the physical and chemical properties of aerogels. Thus, the controlling of pore formation and their network is of significant importance. Aerogels were first developed and investigated by Kistler in the early 1930s [8]. His hypothesis was that the shrinkage of gel was caused by capillary forces appearing during the drying process. As a result of much research, he declared that above the critical temperature of the liquid and at pressure above the liquid's vapor pressure, the liquid's transition into gas will not subject the gel structure to tension. This means that the structure of dry gel is intact [8]. 


\section{Fields of applications}

Aerogel materials can be produced as monolithic blocks or as carpets reinforced by some fiber material [8]. Due to the uncommon thermal properties of aerogels they are mostly used in applications where there is an impact of high temperature and where there is a need to reduce heat losses significantly and effectively. For this reason, fields of applications are found in buildings, especially for thermal windows insulation, supercapacitors, acoustic barriers [9], pipelines, power plants, space vehicles and optical insulations. They are also used as fire protections. However, aerogels represent a state-of-the-art group of thermal insulation materials, the large-scale production is unprofitable. Pure aerogels also have a gentle and fragile structure that is susceptible to fracture. Low mechanical properties make maintenance difficult. Its workability is troublesome due to the formation of dust which can be also hazardous to health. Aerogels are also susceptible to settling over time especially when exposed to vibration or thermal cycling [5]. The settling process can form voids and therefore can contribute to heat losses in void spaces, which is a major drawback for further utilization. As preventing action reinforced aerogel blankets have been developed. Aerogel blankets consist of aerogel particles, fibers and an optional binder [5]. In comparison with monolithic aerogels they exhibit much more durability and stability. In literature there are many mathematical models and experimental research results confirming the outstanding thermal performance of aerogel blankets $[4,5,10-14]$.

\section{Heat transfer in aerogel materials}

The main task of insulation materials is to reduce heat transfer through the insulated construction. Heat transfer mechanisms in insulation materials are composed of three main parts: conduction through solid material, conduction through gas phase and radiation through pores $[8,9]$. Figure 2 shows the relation

Fig. 2. Thermal transport of aerogel materials in dependence of density: 1 - radiation, 2 - gas conduction, 3 - solid conduction, 4 - total heat transfer Source: Husing N., Schubert U.: Aerogels - airy materials: chemistry, structure and properties. Angew. Chem., Int. Ed., 37, 22-45, 1998; Fricke J.: Aerogels. Scientific American, 258, 92, 1988

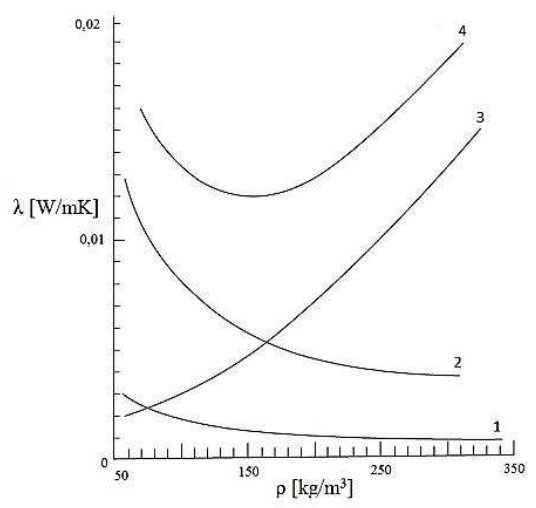


between heat transfer mechanisms in aerogel materials represented by coefficient of thermal conductivity and the density of aerogel.

Aerogels in general exhibit superior thermal insulation characteristics especially for densities around $150 \mathrm{~kg} / \mathrm{m}^{3}$. There is a noticeable increase in thermal conductivity when the material's density is increased due to a raised contribution of the solid conduction component. Simultaneously, radiation and gas components of heat transfer mechanisms tend to decrease.

\section{Characteristics of the investigated material}

Pyrogel XT, which is an example of a novel type of aerogel blanket, was investigated in this paper. It is produced by Aspen Aerogels and is formed of a silica aerogel reinforced with a non-woven glass fiber batting. Such a connection of materials is environmentally friendly due to sand content and no respirable fibers. Figure 3 presents a view of the investigated sample of material adjusted to Poensgen apparatus requirements. The material's sample was cut with a scalpel to a square shape with a side dimension of $0.050 \mathrm{~m}$. The thickness of the investigated materials should be within 1 to $10^{-3} \mathrm{~m}$.

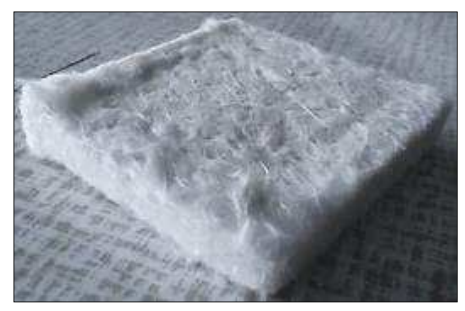

Fig. 3. The real view of the investigated sample of aerogel blanket required for Poensgen apparatus

According to the product data sheet of Pyrogel XT [15], it is a flexible industrial insulation for high temperature applications with a service temperature range from $-40^{\circ} \mathrm{C}$ to $650^{\circ} \mathrm{C}$. Fields of application of Pyrogel XT contain hot piping equipment, towers, tanks, low- and high-temperature ducts etc. Special applications of Pyrogel XT include overwrap systems and high temperature composite systems. Considerable thermal efficiency is achieved by reducing the material's thickness by a rate of 2-5. In comparison with average aerogel, Pyrogel XT is not susceptible to cracking due to excellent bounce-back properties, therefore it can withstand high impact loads without damage. This material is also lightweight, fire resistant, and hydrophobic. Other selected properties and product performance data with corresponding standards are included in Table 1.

Due to the complexity of aerogel materials, its thermal conductivity depends on such parameters like configuration of the internal structure (opened or closed pores, pore size, porosity distribution etc.) and pressure and temperature of application. As far as the Pyrogel XT thermal conductivity is concerned, it was determined according to the ASTM C 177 standard. Thermal conductivity 
distribution declared by the manufacturer was given in the form of a diagram as a function of temperature which is shown in Figure 4.

Table 1. Product performance data of Pyrogel XT (according to [15])

\begin{tabular}{|l|l|l|}
\hline \multicolumn{1}{|c|}{ Property } & \multicolumn{1}{|c|}{ Results } & \multicolumn{1}{|c|}{ Test procedure } \\
\hline Compressive strength & $\begin{array}{l}\text { Stress at } 10 \% \text { strain }=78,3 \mathrm{kPa} \\
\text { Stress at } 25 \% \text { strain }=255,2 \mathrm{kPa}\end{array}$ & ASTM C 165 \\
\hline $\begin{array}{l}\text { Estimation of maximum use tem- } \\
\text { perature }\end{array}$ & $650^{\circ} \mathrm{C}$ & ASTM C 447 \\
\hline $\begin{array}{l}\text { Linear shrinkage under soaking } \\
\text { heat }\end{array}$ & $<2 \%\left(650^{\circ} \mathrm{C}\right)$ & ASTM C 356 \\
\hline Water vapor sorption & $<5 \%$ (by weight $)$ & ASTM C 1104 \\
\hline
\end{tabular}

Fig. 4. Thermal conductivity distribution of Pyrogel XT depending on the temperature

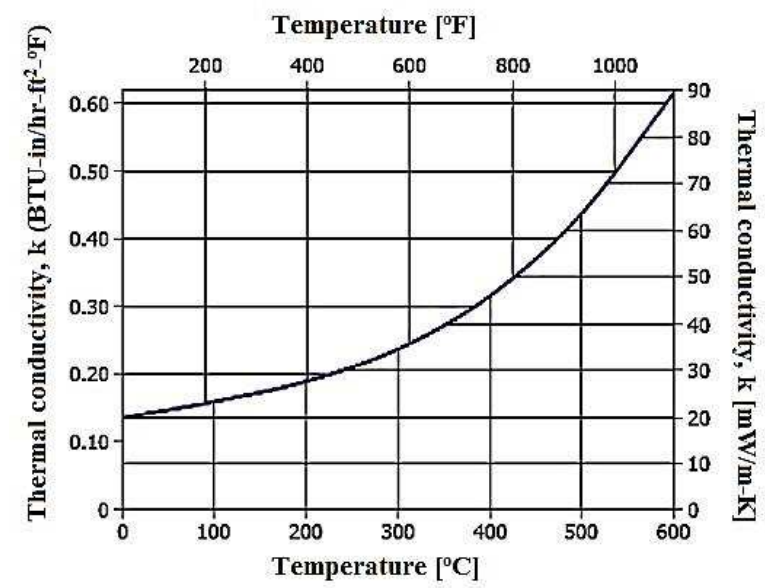

\section{Experimental investigation}

\subsection{Poensgen apparatus}

In this paper, thermal conductivity of Pyrogel XT was also investigated experimentally to validate its thermophysical properties. Experimental research of Pyrogel XT was first made on a simplified Poensgen apparatus in which the application of Fourier's law solution was used. The Poensgen apparatus is dedicated for measurements of the thermal conductivity of insulation materials within the range from 0.02 to $3.0 \mathrm{~W} / \mathrm{mK}$ [16]. Coefficient of thermal conductivity measurement is based on temperature field solution during unidirectional, steady heat conduction for an unlimited flat sheet model of thickness $\delta$ [16]. There are two variations of Poensgen apparatus. Simplified modification consists of the heater and the cold water cooler among which the material's sample is placed, which is presented in Figure 5. There is also the hot water plate located on the other side of the heater behind the thin layer of cork. Its function is to ensure 
unidirectional heat flux, which flows from the heater through the sample to the cooler. The hot water plate has the same temperature as the heater. The surfaces of the heater, the sample of material, the cooler and the hot water plate must adhere precisely to each other. On the top of the pile the crucified shape yoke with bolt is applied and connected to four stationary pins. The entire thermal setup is located inside the removable upper container which is poured with thermal insulation material (crumbled foamed polystyrene) and stored in the bottom container. This ensures thermal protection of the system. Figure 6 shows the real view of the entire test stand for thermal conductivity research which is located in the Department of Thermodynamics on Rzeszow University of Technology.

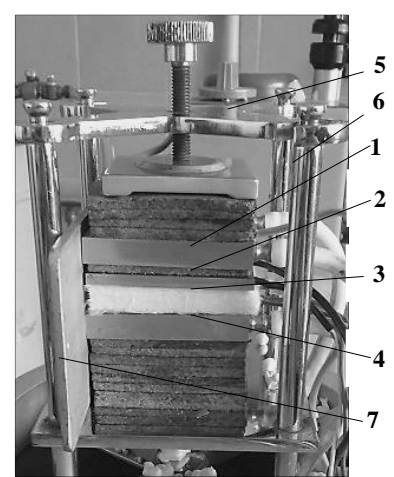

Fig. 5. The view of internal parts of Poensgen apparatus: 1 - hot water sheet, 2 - heater, 3 - material's sample, 4 - cooler, 5 - crucified shape yoke, 6 - pin, 7 compensating plate

Source: own elaboration

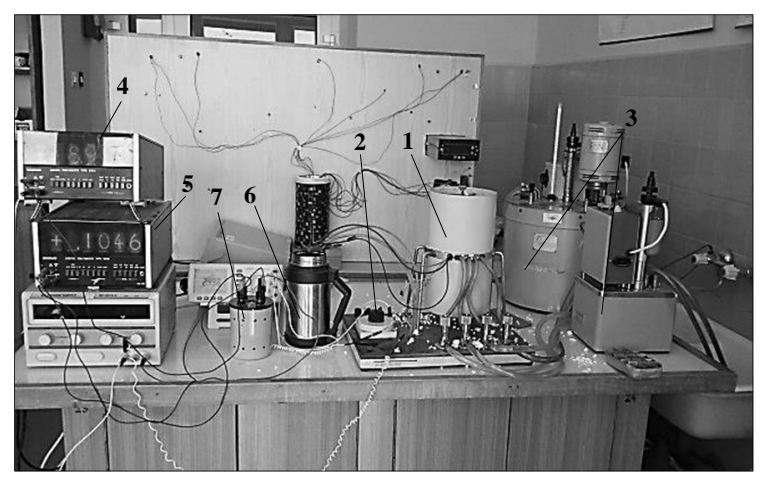

Fig. 6. The view of experimental test stand for thermal conductivity measurements: 1 - Poensgen apparatus, 2 - switch, 3 - thermostats, 4 - ammeter, 5 - voltmeter, 6 - Dewar flask, 7 - resistor

Source: own elaboration

Measurement of the thermal power of the heater is carried out indirectly by measuring the voltage drop and intensity of current which flows through the heating spiral. Measurements of the temperature of the heater, the cooler and the heated plate surface are performed using thermocouples in which hot junctions are soldered to its surfaces and reference junctions are placed in a Dewar flask. Thermocouple wires are connected to the multifunctional switch located on the front panel. Thermal conductivity calculations are based on the average values obtained during main measurements. Thermal conductivity of the investigated sample is described by the formula:

$$
\lambda=\frac{\dot{Q} \delta}{A \Delta T}
$$

where: $\dot{Q}=\mathrm{UI}$ - thermal power of the heater, $\mathrm{W}$,

$\delta$ - material's thickness, m, 
A - heat transfer surface, $\mathrm{m}^{2}$,

$\Delta \mathrm{T}=\left(\mathrm{T}_{\mathrm{wc}}-\mathrm{T}_{\mathrm{wz}}\right)-$ average temperature gradient between the hot plate and the cooler, $\mathrm{K}$,

To obtain the temperature difference, the thermocouple voltage signal had to be transformed into a temperature scale with use of calibration chart. To increase the accuracy of the method three samples were investigated. The material's surface area and the thickness were measured by an electronic caliper before every measurement on several locations of the sample. The average values were obtained. This was important because of the material's heterogeneity. Readings of researched values can be started when temperatures of the heater and the hot water plate are equal. Measurements were carried out at an ambient temperature of $21^{\circ} \mathrm{C}$. The accuracy of the method is $\pm 7 \%$. Results were collected in Table 2 .

Table 2 . Thermal conductivity research results obtained from Poensgen apparatus

\begin{tabular}{|c|c|c|c|c|c|c|c|c|}
\hline $\begin{array}{c}\text { No. of } \\
\text { trial }\end{array}$ & $\begin{array}{c}\mathrm{A} \cdot 10^{4} \\
{\left[\mathrm{~m}^{2}\right]}\end{array}$ & $\begin{array}{c}\delta \cdot 10^{3} \\
{[\mathrm{~m}]}\end{array}$ & $\begin{array}{c}\mathrm{U}_{\mathrm{G}} \\
{[\mathrm{V}]}\end{array}$ & $\begin{array}{c}\mathrm{UwC} \\
{[\mathrm{mV}]}\end{array}$ & $\begin{array}{c}\mathrm{UwZ} \\
{[\mathrm{mV}]}\end{array}$ & $\begin{array}{c}\mathrm{I} \\
{[\mathrm{A}]}\end{array}$ & $\Delta \mathrm{T}[\mathrm{K}]$ & $\boldsymbol{k}\left[\frac{\boldsymbol{W}}{\mathbf{m K}}\right]$ \\
\hline 1 & 25.738 & 8.70 & 7.194 & 2.363 & 0.813 & 0.0843 & 38.75 & $\mathbf{0 . 0 5 4}$ \\
\hline 2 & 25.049 & 9.24 & 7.276 & 2.430 & 0.804 & 0.0853 & 40.65 & $\mathbf{0 . 0 5 6}$ \\
\hline 3 & 24.998 & 10.02 & 7.801 & 2.735 & 0.846 & 0.0914 & 47.22 & $\mathbf{0 . 0 6 1}$ \\
\hline 4 & 24.999 & 10.02 & 5.927 & 1.948 & 0.840 & 0.0693 & 27.70 & $\mathbf{0 . 0 5 9}$ \\
\hline \multicolumn{10}{|c|}{ mean value } & $\mathbf{0 . 0 5 8}$ \\
\hline \multicolumn{10}{|c|}{ standard deviation of mean } & $\mathbf{0 . 0 0 3}$ \\
\hline
\end{tabular}

\subsection{Unitherm ${ }^{\mathrm{TM}} 2022$ thermal conductivity instrument}

The second approach in the thermal conductivity investigation included the Unitherm $^{\mathrm{TM}} 2022$ instrument (Fig. 7). The model 2022 is a fully computerized system. According to the user's manual of the Model 2022 [17], it is used for measuring the thermal conductivity of such materials like metals, ceramics, polymers, composites, glass, rubber and graphite products. The Model 2022 can be also used for testing thin specimens like paper products or plastic films. Thermal conductivity is measured by the ASTM E1530 guarded heat flow meter method. The view of the experimental test section is presented in figure 8. A specimen of the researched material is held under a reproducible compressive load between two polished metal surfaces, each controlled at a different temperature. The lower contact surface is a part of a calibrated heat flux transducer. As heat flows from the upper surface through the specimen to the lower surface, an axial temperature gradient is established in the stack. By measuring the temperature difference across the specimen (between the upper and the lower surface plates in contact with the specimen) along with the output from the heat flux transducer, 
thermal conductivity of the specimen can be determined when its thickness is known.

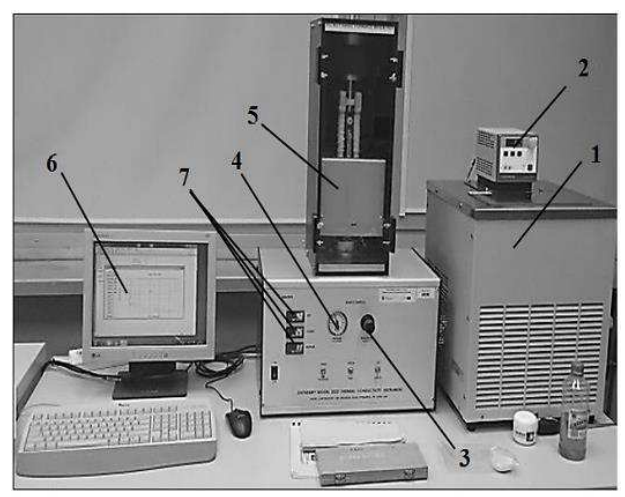

Fig. 7. The view of the experimental test stand: 1 - ultra thermostat, 2 - regulator, 3 - air pressure regulator, 4 - air pressure gauge, 5 - guard furnace, 6 - computer control program, 7 - heater PID controllers

Source: own elaboration

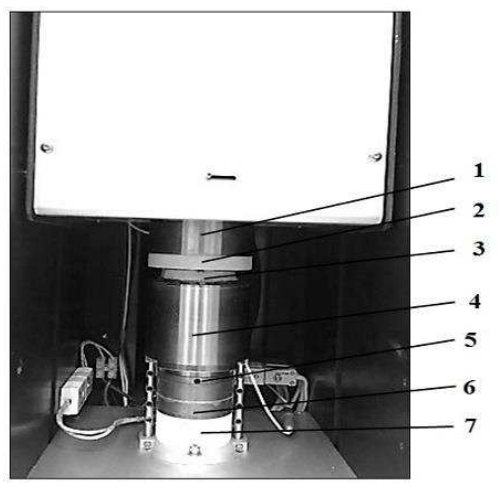

Fig. 8 . The view of test section: 1 - top heater, 2 - upper plate, 3 - test specimen, 4 - lower plate, 5 - reference calorimeter, 6 - bottom heater, 7 - heat sink

Source: own elaboration

At thermal equilibrium, the Fourier heat flow equation applied to the test specimen becomes:

$$
R_{S}=\frac{T_{u}-T_{m}}{Q}-R_{\text {int }}
$$

where: $R_{s}$ - thermal resistance of the test specimen, $\mathrm{m}^{2} \mathrm{~K} / \mathrm{W}$,

$\mathrm{T}_{\mathrm{u}}$ - upper plate surface temperature, $\mathrm{K}$,

$\mathrm{T}_{\mathrm{m}}$ - lower plate surface temperature, $\mathrm{K}$

$\mathrm{Q}$ - heat flux through the test specimen, $\mathrm{W} / \mathrm{m}^{2}$,

$\mathrm{R}_{\text {int }}$ - total interface resistance between specimen and surface plates, $\mathrm{m}^{2} \mathrm{~K} / \mathrm{W}$.

The thermal resistance of the test specimen is defined as:

$$
R_{S}=\frac{d}{\lambda}
$$

where: $\mathrm{d}$ - specimen thickness, $\mathrm{m}$,

$\lambda$ - thermal conductivity, $\mathrm{W} / \mathrm{mK}$.

The heat flux through the specimen is measured with a transducer located just below the specimen. The heat flux transducer consists of a reference calo- 
rimeter with high conductivity surface plates on either side. The heat flux is determined by measuring the temperature difference across the reference calorimeter.

$$
Q=N\left(T_{m}-T_{L}\right)
$$

where: $\mathrm{N}$ - reference calorimeter heat transfer coefficient, $\mathrm{W} / \mathrm{m}^{2} \mathrm{~K}$,

$\mathrm{T}_{\mathrm{L}}$ - bottom heater temperature, $\mathrm{K}$.

The specimen thermal resistance can be expressed in the form:

$$
R_{s}=F\left(\frac{\Delta T_{s}}{\Delta T_{r}}\right)-R_{\text {int }}
$$

where: $\mathrm{F}$ - proportionality constant,

$\Delta \mathrm{T}_{\mathrm{s}}=\left(\mathrm{T}_{\mathrm{u}}-\mathrm{T}_{\mathrm{m}}\right)$ - temperature difference across the specimen,

$\Delta \mathrm{T}_{\mathrm{r}}=\left(\mathrm{T}_{\mathrm{m}}-\mathrm{T}_{\mathrm{L}}\right)-$ temperature difference across the reference calorimeter.

When the thermal resistance of the test specimen is assigned, the thermal conductivity is then calculated from Equation (5) and shown on computer screen. In the Model 2022 the ideal conditions (no heat loss or gain along the outer surface of the test stack) during the test are assumed. Before testing the section must be calibrated first to obtain the relationship between $\mathrm{R}_{\mathrm{s}}$ and $\Delta \mathrm{T}$. The calibration procedure consists of testing a minimum of 3 specimens of known thermal resistance. Thermal conductivity is measured with an estimated accuracy of $\pm 3 \%$ to $\pm 8 \%$ depending on the thermal resistance of the specimen. The results were collected in Table 3 .

\begin{tabular}{|c|c|c|c|c|c|c|}
\hline $\begin{array}{c}\text { No. of } \\
\text { trial }\end{array}$ & $\begin{array}{c}\text { Mean } \\
\text { specimen tem- } \\
\text { perature }\left[{ }^{\circ} \mathrm{C}\right]\end{array}$ & $\begin{array}{l}\Delta \mathrm{T}_{\mathrm{s}} \\
{\left[{ }^{\circ} \mathrm{C}\right]}\end{array}$ & $\begin{array}{l}\Delta \mathrm{T}_{\mathrm{r}} \\
{\left[{ }^{\circ} \mathrm{C}\right]}\end{array}$ & $\begin{array}{c}R_{S} \\
{\left[\frac{m^{2} K}{W}\right]}\end{array}$ & $\mathrm{d} \cdot 10^{3}[\mathrm{~m}]$ & {$\left[\begin{array}{c}\lambda \\
m K\end{array}\right]$} \\
\hline 1 & 28.91 & 28.77 & 1.13 & 1.91 & 8.3 & 0.043 \\
\hline 2 & 29.37 & 28.94 & 1.42 & 1.52 & 8.3 & 0.054 \\
\hline 3 & 29.40 & 28.92 & 1.35 & 1.61 & 8.3 & 0.052 \\
\hline \multicolumn{6}{|c|}{ mean value } & 0.049 \\
\hline \multicolumn{6}{|c|}{ standard deviation of mean } & 0.006 \\
\hline
\end{tabular}

Table 3. Thermal conductivity research results obtained from Unitherm ${ }^{\mathrm{TM}} 2022$ 


\section{Summary}

The aim of the study was the brief introduction in the field of aerogel materials as thermal insulators. The basic properties, applications and results of experimental research were presented. The main content of the paper was a simple experimental validation of the thermophysical properties obtained with use of two conventional measuring methods. An investigation of the Poensgen apparatus was carried out at average temperature difference between the hot plate and the cooler of $38.5^{\circ} \mathrm{C}$. The average calculated thermal conductivity was $0.058 \frac{\mathrm{W}}{\mathrm{mK}}$. The research on Unitherm ${ }^{\mathrm{TM}} 2022$ instrument was carried out with a mean specimen temperature of $29.2^{\circ} \mathrm{C}$ and the calculated thermal conductivity was $0.049 \frac{\mathrm{W}}{\mathrm{mK}}$. The results obtained are in good correspondence, however there is a significant divergence in comparison with data declared by the manufacturer. The thermal conductivity distribution was determined with the use of the guarded hot plate apparatus with respect to ASTM C 177 standard. According to Fig. 4 thermal conductivity at ambient temperature should be around $0.025 \frac{\mathrm{W}}{\mathrm{mK}}$ (declared thermal conductivity at $0^{\circ} \mathrm{C}$ is $0.02 \frac{\mathrm{W}}{\mathrm{mK}}$ ) which gives an error of about $50 \%$. Suggestions for such a disagreement may include high thermal contact resistance of investigated sample resulting from the material's preparation. Various fiber orientations in the investigated test specimen may have contributed to the differences. Also the selection of measurement method can introduce errors. Thermal insulation material which fills the interior of the Poensgen apparatus does not ensure the unidirectional heat flux through the test specimen.

Thermal conductivity depends on many parameters, including the temperature, the density, the alignment of the sample towards the heat flux direction etc. Due to the general character of the presented investigation, the explanation of the mentioned problem requires more detailed analysis and complex measurements.

Regardless of the divergence presented, the aerogel blanket may be classified as a promising and effective thermal insulation material.

\section{References}

[1] http://www.aerogel.org/?p=992, dostęp 15.09.2016.

[2] http://www.aerogel.org/?p=3 dostęp 15.09.2016.

[3] Zhao J., Duan Y., Wang X., Wang B.: Radiative properties and heat transfer characteristics of fiber-loaded silica aerogel composites for thermal insulation, Int. J. Heat Mass Transfer 55 (2012) 5196-5204.

[4] Yuan B., Ding S., Wang D., Wang G., Li H.: Heat insulation properties of silica aerogel/glass fiber composites fabricated by press forming, J. Materials Letters 75 (2012) 204-206. 
[5] Hoseini A., McCgue C., Andisheh-Tadbir M., Bahrami M.: Aerogel blankets: From mathematical modeling to material characterization and experimental analysis, Int. J. Heat Mass Transfer, 93 (2016) 1124-1131.

[6] Furmański P., Wiśniewski T.S., Banaszek J.: Izolacje cieplne. Mechanizmy wymiany ciepła, właściwości cieplne i ich pomiary, OW PW, Warszawa 2006.

[7] http://www.aerogel.org/?p=4, dostęp 15.09.2016.

[8] Berge A., Johansson P.: Literature Review of High Performance Thermal Insulation, Chalmers University of Technology, Gothenburg, Sweden 2012, Report 2012:2.

[9] Yu C-H., Fu Q.J., Tsang S.C.E.: Aerogel materials for insulation in buildings, University of Oxford, UK, Materials for Energy Efficiency and Thermal Comfort in Buildings Chapter 13, Woodhead Publishing Limited 2010.

[10] Laskowski J., Milow B., Ratke L.: Aerogel-aerogel composites for normal temperature range thermal insulations, J. Non-Crystalline Solids, 441 (2016) 42-48.

[11] He J., Li X., Su D., Ji H., Wang X.: Ultra-low thermal conductivity and high strength of aerogel/fibrous ceramic composites, J. European Ceramic Society, 36 (2016) 1487-1493.

[12] Baetens R., Jelle B.P., Gustavsen A.: Aerogel insulation for building applications: a state-of-the-art review, Energy Buildings, 43 (2011) 761-769.

[13] Cohen E., Glicksman L.: Thermal properties of silica aerogel formula, J. Heat Transfer, 137 (2015) 081601-1 - 081601-8.

[14] Wei G., Liu Y., Zhang X., Yu F., Du X.: Thermal conductivities study on silica aerogel and its composite insulation materials, Int. J. Heat Mass Transfer, 54 (2011) 2355-2366.

[15] http://crossroadsci.com/Portals/0/documents/data_sheets/industrial/Aspen_Aerogels_Pyrogel_XT.pdf

[16] Grosicki S., Smusz R., Wilk J., Wolańczyk F.: Wymiana ciepła - eksperymenty. Materiały pomocnicze, OW PRz, Rzeszów 2014.

[17] Unitherm ${ }^{\mathrm{TM}}$ thermophysical instruments: Operating and software manual, Anter Corporation USA, version 2.9, May 2010.

\section{WŁAŚCIWOŚCI, ZASTOSOWANIE I BADANIE CIEPLNE AEROŻELI}

\footnotetext{
Streszczenie

Spośród wielu wyrobów termoizolacyjnych stosowanych w przemyśle maty aerożelowe zyskują duże zainteresowanie ze względu na wyjątkowe właściwości oraz szeroki zakres zastosowań. W pracy zaprezentowano właściwości, obszary zastosowań i wyniki eksperymentalnych badań cieplnych maty aerożelowej Pyrogel XT, będącej nowoczesnym materiałem termoizolacyjnym. Badany materiał jest złożony z aerożelu krzemowego wzmocnionego dodatkiem włókna szklanego. W porównaniu do tradycyjnych materiałów termoizolacyjnych Pyrogel XT odznacza się szczególnymi właściwościami, do których należy najniższa, spośród wszystkich dostępnych termoizolacji przemysłowych, wartość współczynnika przewodzenia ciepła przy jednocześnie szerokim temperaturowym zakresie stosowania $\left(-40^{\circ} \mathrm{C} \div 650^{\circ} \mathrm{C}\right)$. Pyrogel XT posiada również najniższy współczynnik przewodzenia ciepła spośród znanych ciał stałych. Badania eksperymentalne właściwości termofizycznych aerożelu Pyrogel XT przeprowadzono metoda tradycyjną oraz me-
} 
todami nowoczesnymi. Do badań tradycyjnych wykorzystano uproszczony jednopłytowy aparat Poensgena. W badaniach metodą nowoczesną wykorzystano stanowisko badawcze Unitherm ${ }^{\mathrm{TM}}$ 2022 wyposażone $\mathrm{w}$ miernik przepływu strumienia ciepła pracujący zgodnie $\mathrm{z}$ normą ASTM E1530. Wyniki uzyskane z obu urządzeń porównano i poddano analizie.

Słowa kluczowe: mata aerożelowa, przewodność cieplna, aparat Poensgena, strumień ciepła

DOI: $10.7862 / \mathrm{rm} .2017 .20$

Otrzymano/received: 11.04 .2017

Zaakceptowano/accepted: 17.05.2017 